\title{
POLLEN EVIDENCE OF HISTORICAL FOREST DISTURBANCE ON THE WASATCH PLATEAU, UTAH
}

\author{
Jesse L. Morris ${ }^{1,3}$, Andrea R. Brunelle ${ }^{1}$, and A. Steven Munson ${ }^{2}$
}

\begin{abstract}
Environmental indicators from lake sediments provide excellent opportunities to improve understanding of forest disturbance processes and corresponding changes in forest composition. Our research provides a methodology for assessing recent, historic, and prehistoric disturbances using lacustrine sediment records. We collected sediment cores from Blue Lake, a small subalpine lake on the Wasatch Plateau in central Utah. These cores record environmental changes caused by both spruce beetle (Dendroctonus rufipennis Kirby) and human (logging and livestock grazing) modification. We observed deteriorated insect remains in the lake sediments. These remains correspond temporally with a historic spruce beetle outbreak, though alkaline conditions in the lake water may have inhibited preservation of bark beetle remains. Pollen data reveal that despite the unprecedented level of mortality among Engelmann spruce (Picea engelmannii Parry ex Engelm.) resulting from the spruce beetle epidemic, logging activities subsequent to Euro-American settlement appear to be the most severe disturbance to the Blue Lake watershed over the last 750 years.
\end{abstract}

Key words: spruce beetle, Dendroctonus rufipennis, Engelmann spruce, Picea engelmannii, fire, pollen, grazing, logging, lake sediment.

Forest ecosystems are constantly being altered by both human and natural forces. Logging, forest fragmentation, and wildfire are regarded as primary disturbance agents of forested landscapes in the western United States (e.g., Veblen et al. 1991, Mattson 1996, Logan and Powell 2001, Kulakowski and Veblen 2003). Understanding the interconnection and interaction among forest disturbance events, both natural and human caused, continues to be an important area of research, particularly during climate change (Hebertson and Jenkins 2008).

Human-caused disturbances, such as logging, mining, livestock grazing, and agriculture, profoundly alter the appearance and ecology of the landscape. Scientists assessing the impacts of Euro-American settlement utilize a variety of methods, both qualitative and quantitative, to gauge the magnitude and determine the trends of change caused by human activities (Stewart 1941, Schmid and Hinds 1974, Mattson 1996, Dull 1999, Hall 2001, Donato et al. 2006, Gillson and Hoffman 2007). Nonhuman disturbances, such as wildfire, insect epidemics, windthrow, and avalanches, are often the catalyst for maintaining forest vigor and promoting forest regeneration (Kolb et al. 1994, Mattson 1996,
Logan and Powell 2001, Kulakowski and Veblen 2003, Raffa et al. 2008).

In subalpine spruce-fir forests in the central and southern Rockies, spruce beetle (Dendroctonus rufipennis Kirby) is regarded as the most significant natural disturbance agent of this forest type (Schmid and Frye 1977, Baker and Veblen 1990, Holsten et al. 1999, DeRose and Long 2007). The return interval for landscape-scale spruce beetle epidemics has been estimated at 116.5 years, assessed from tree-ring records spanning the last several centuries in Colorado (Veblen et al. 1994). Fire is also an important disturbance agent occurring in spruce-fir forests (Jenkins et al. 1998, Peet 2000). Infrequent, high-severity fires in spruce/fir (also estimated using tree-ring analyses) suggest a mean fire-return interval of 200-400 years (Whipple and Dix 1979, Romme and Knight 1981, Rebertus et al. 1992, Veblen et al. 1994, Kipfmueller and Baker 2000). The role of lowseverity fires is less resolved, and low-severity fires are believed to play a smaller ecological role in high-elevation forests, such as those found in Colorado and Utah (Kulakowski et al. 2003). The fire-return interval in these high-elevation ecosystems exceeds the window of scientific observation, and few data sets presently

${ }^{1}$ University of Utah, Department of Geography RED Lab, Salt Lake City, UT 84112

${ }^{2}$ USDA Forest Service, Forest Health Protection, Ogden, UT 84401.

${ }^{3}$ E-mail: jesse.morris@geog.utah.edu 


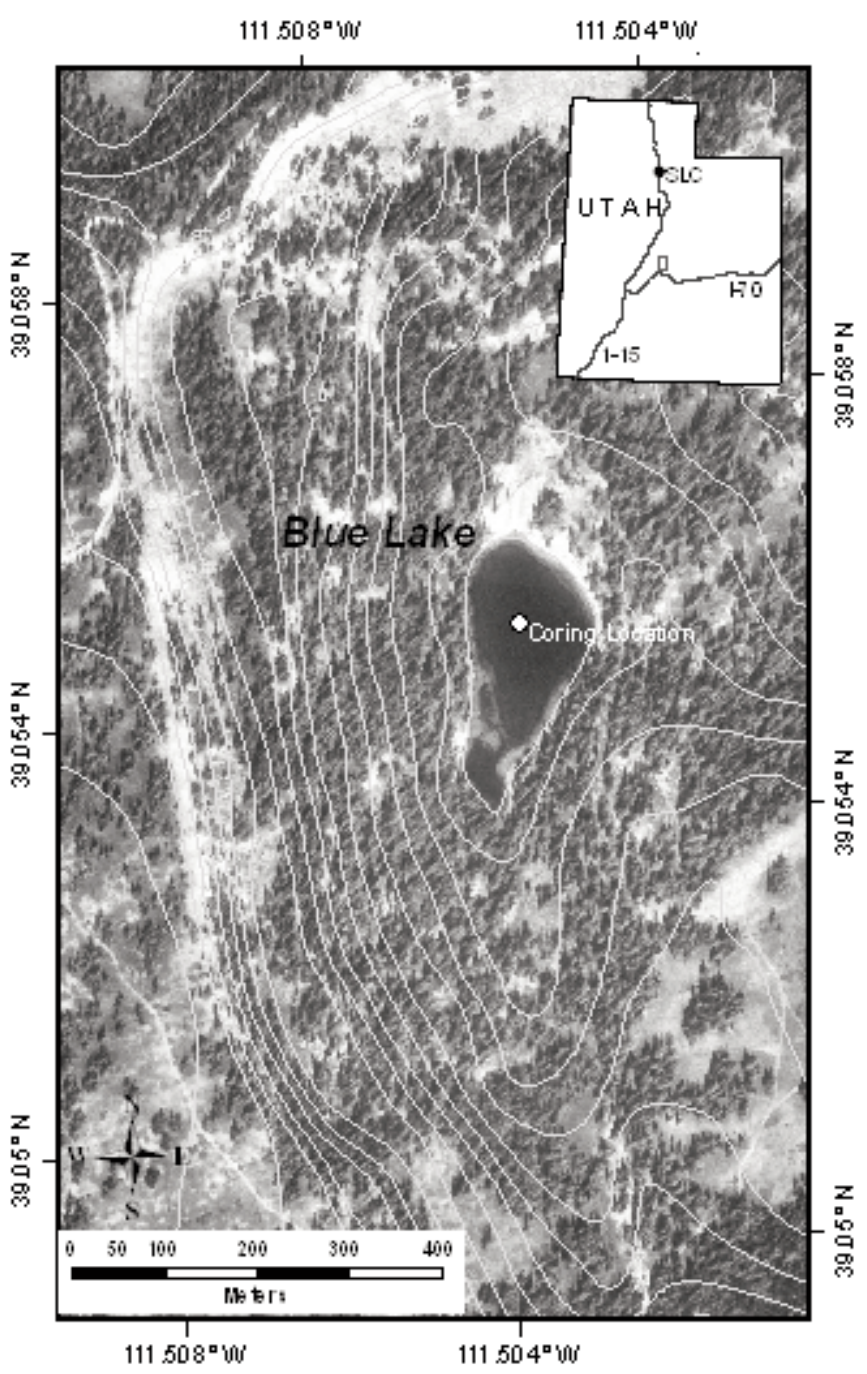

Fig. 1. Location of Blue Lake in central Utah.

exist for understanding these events. Furthermore, the interaction between spruce beetle and antecedent or subsequent wildfire within the host range of this insect is not presently resolved but remains a vitally important research topic (Bebi et al. 2003).

A comprehensive understanding of presettlement disturbance processes and vegetative structure is important for land management strategies designed to minimize economic and aesthetic losses from current and/or future spruce beetle epidemics. Because historic records of presettlement vegetative conditions are sparse, environmental proxies (e.g., lake sediments and tree rings) are important resources in reconstructing past ecological structure and patterns of disturbance.

Utilizing lake sediments to provide information about presettlement forest-disturbance events allows us to raise several important questions: (1) How are the signals of historically documented disturbances recorded in the sediments? (2) What type of unique sedimentological signature do historical disturbances exhibit? (3) How does the frequency and interaction of disturbance events compare before and after settlement?

To answer these questions, we used lake sediments and historical documentation to reconstruct a pre- and postsettlement record 
of disturbance on the Wasatch Plateau, Utah (Fig. 1). Our research provides information on presettlement vegetative structure and also introduces a palynological methodology using fossil pollen and charcoal from lake sediments to assess effects of land-use change, wildfire, and spruce beetles on vegetative structure.

\section{Wasatch Plateau Epidemic}

The spruce beetle outbreak on the Wasatch Plateau over the past 2 decades is the largest recorded epidemic in Utah (Dymerski et al. 2001). Spruce beetle populations became established in downed spruce that fell due to slope failure in 1986 in the Twelvemile Creek drainage east of Mayfield, Utah (Dymerski et al. 2001). In Sanpete, Emery, Carbon, and Sevier counties, the USDA Forest Service, Intermountain Region, Forest Health Protection (FHP) staff observed and documented 715,000 dead trees resulting from spruce beetle activity in 133,000 acres of subalpine forests between 1991 and 2006 (Dymerski et al. 2001; R. Halsey, personal communication, May 2007). Concerns over elevated availability of wildfire fuel have led to salvage logging in some of the affected areas to reduce fuel loads (Dymerski et al. 2001). Fluctuations in bark beetle populations (and resulting tree mortality) depend on several factors: climate, seasonality, species composition, stand density, and tree diameters (Schmid and Frye 1977, Hansen et al. 2001a, 2001b). It has been suggested that warming temperatures during the 20th century have caused beetle reproductive cycles to accelerate, triggering widespread beetle activity in a number of western states (Logan and Powell 2001, Hebertson 2003).

\section{Site DESCRIPTION}

Blue Lake $\left(39^{\circ} 3^{\prime} 24^{\prime \prime} \mathrm{N}, 111^{\circ} 59^{\prime} 12^{\prime \prime} \mathrm{W}\right.$; elevation: $3240 \mathrm{~m}$ above sea level) is a small subalpine lake located in a north-facing cirque basin on the Wasatch Plateau in Sanpete County, Utah (Fig. 1). This plateau is found on the transition between the geologic provinces of the Great Basin and Colorado Plateau and was glaciated during the most recent Ice Age (Spieker and Billings 1940, Osborn and Bevis 2001, Wannamaker et al. 2001, Marchetti et al. 2005). Limestone (Flagstaff Formation) dominates the surface bedrock on much of the plateau, resulting in scattered carbonate-rich cirque lakes with somewhat alkaline $\mathrm{pH}$.
The climate in this region of the Intermountain West is characterized by long, cold winters with heavy snow accumulation and relatively brief, mild summers with significant precipitation from convective thunderstorms. Bimodal precipitation regimes have been described and documented in south central Utah. These regimes are attributed to the dominance of polar air masses during the winter months and the recirculation of North American monsoonal moisture and convective storms during the late summer months (Mitchell 1976, Petersen 1994, Mock 1996, Anderson et al. 1999).

The surface area of Blue Lake is approximately 1.2 ha (3 acres), with a maximum water depth of about $8 \mathrm{~m}$. The lake is fed by 2 seasonal springs, located south of the lake on the cirque headwall. Blue Lake is dammed by a recessional moraine to the north that has been incised by one intermittent outflow channel. Blue Lake is currently surrounded by an opencanopy ghost forest (Logan and Powell 2001) of dead overstory Engelmann spruce (Picea engelmannii Parry ex. Engelm.) that is interspersed with living subalpine fir (Abies lasiocarpa [Hook.] Nutt).

A severe spruce beetle epidemic beginning in 1986 caused extensive mortality in P. engelmannii across the study area. FHP aerial and ground surveys estimated $P$. engelmannii mortality from the spruce beetle epidemic to be $>90 \%$ in spruce $<12.7 \mathrm{~cm}$ in diameter (Dymerski et al. 2001). This large-scale epidemic provided an opportunity to calibrate a historically documented, high-severity spruce beetle epidemic with a lake sediment record.

The forest understory surrounding Blue Lake is composed primarily of currant (Ribes) and members of the legume (Fabaceae) and sunflower (Asteraceae) families. Immediately north of the lake is a subalpine meadow dominated by various grasses (Poaceae) and Asteraceae, specifically alpine sagebrush (Artemisia borealis) and occasional specimens of limber pine (Pinus flexilis).

\section{Methods}

Five cores were collected at Blue Lake in August 2005 using piston coring devices. Two of these cores, the short core (BL $05 \mathrm{SC}$ ) and one of the long cores (BL $05 \mathrm{D})$, were used for our analyses. Both cores were retrieved in the deepest part of the lake (8 $\mathrm{m}$ of water). All 


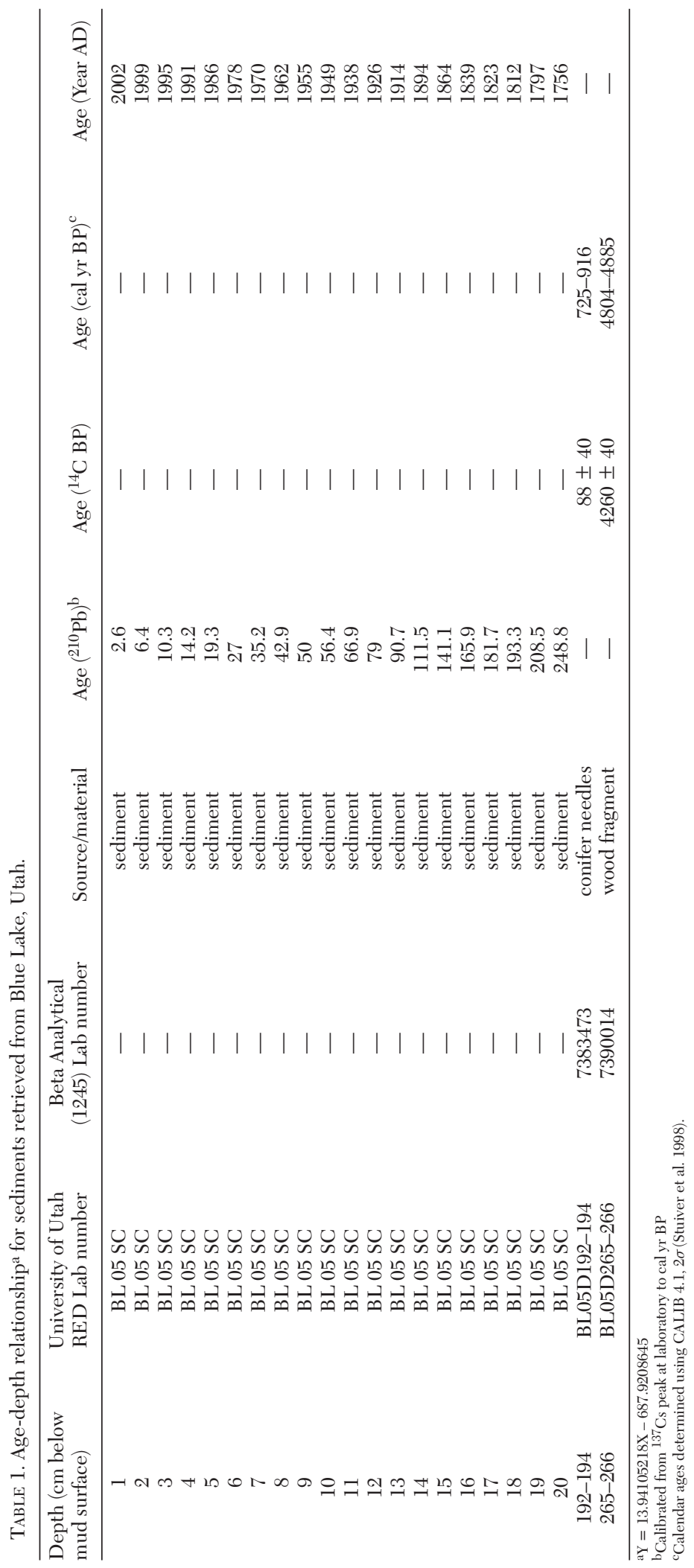


samples and cores were placed into cold storage in the Records of Environment and Disturbance Laboratory (RED Lab) at the University of Utah.

The chronology for the Blue Lake cores is summarized in Table 1, where radiocarbon and lead-210 dates are presented. Accelerated mass spectrometry (AMS) radiocarbon dates were provided by Beta Analytic. Lead-210 dates were provided by Dr. James Budahn, at the U.S. Geological Survey laboratory in Denver, Colorado. Several Abies needles and one wood fragment were submitted for radiocarbon analysis to establish chronological control for BL 05 D. Radiocarbon dates were calibrated from ${ }^{14} \mathrm{C}$ ages to calendar years using CALIB 4.1 (Stuiver et al. 1998).

Pollen samples were collected at 1-cm intervals throughout $\mathrm{BL} 05 \mathrm{SC}$ and then at $8-\mathrm{cm}$ intervals throughout $\mathrm{BL} 05 \mathrm{D}$. The variation in sampling intervals reflects an interest in the modern (historical) portion of the record. Each cubic centimeter (cc) was processed to isolate pollen, following methods established by Faegri et al. (1989). Lycopodium, an exotic spore, was added as a tracer. Processed samples were preserved in silicone oil. Slide-mounted pollen samples were examined using light microscopy at $500 \mathrm{X}$ and counted to a minimum of 300 grains. Grain identification was aided by reference slides and literature (e.g., Erdtman 1952, Bassett et al. 1978, Kapp et al. 2000). Unknown, degraded, or obscured pollen grains were tabulated and did not exceed more than $1 \%$ of total pollen counts for any sample.

Five-cc charcoal samples were taken at every $1 \mathrm{~cm}$ of the core. Each sample was analyzed by methods presented in Whitlock and Millspaugh (1996). Deviation from their methodology was limited to the use of sodium hexametaphosphate $\left(50 \mathrm{~g} \cdot \mathrm{L}^{-1}\right)$ as a disaggregating agent in lieu of Calgon ${ }^{\mathrm{TM}}$. Charcoal was disaggregated from the sediment matrix using 125and 250-micron sieves. Particles of these sizes have been closely associated with historically observed local fires (Whitlock and Millspaugh 1996).

For each 5-cc charcoal sample, particles were identified and counted using light microscopy at 10-40X. Charcoal identification was based on the following 3 characteristics, as noted by Clark (1988): uniform black color, iridescent sheen, and visible cell structure. Raw charcoal counts were converted to charcoal accumulation rates (CHAR) by multiplying raw charcoal counts by the sedimentation rates $\left(\mathrm{cm} \cdot \mathrm{y}^{-1}\right)$. Fire events were identified visually from CHAR plots. During charcoal analysis, the sediment samples were also scanned for Dendroctonus remains. While many of the plant and insect remains found in lake sediment are not truly fossilized, they are still commonly referred to as macro- and microfossils in the paleoecological literature (e.g., Birks 2001) and will be referred to as such.

Loss on ignition (LOI) was performed at 8-cm intervals throughout the core. Sediments were placed in porcelain crucibles and heated to 100,550 , and $900{ }^{\circ} \mathrm{C}$ to determine the percent water, organic content, and carbonate content, respectively. This information can be useful in understanding changes in productivity within the lake and erosion within the lake basin. An understanding of these changes in turn clarifies the ecological significance of disturbance events (Dean 1974).

Magnetic susceptibility was performed at 1-cm intervals using a Bartington ring sensor equipped with a 75-mm aperture. The Blue Lake cores were run horizontally and end-toend through the ring sensor. Measurements were taken at $1-\mathrm{cm}$ intervals, and all values were in standard increments (SI). Magnetic-susceptibility data are used to gauge changes in source material of accumulating sediments, specifically material derived from organic matter versus material derived from bedrock. Shifts in the sediment content can often be diagnostic of a fire disturbance event or other event that removes ground cover (e.g., logging or overgrazing) within the watershed (Gedye et al. 2000).

\section{RESUlts}

The presettlement period of the Blue Lake sedimentary record is subdivided into 3 broad zones associated with variability in hemispheric climate: termination of the Medieval Climate Anomaly (MCA; 750-700 calendar years before present [cal yr BP]), transition period (700-500 cal yr BP), and Little Ice Age (LIA; 500-150 cal yr BP) (Bradley and Jones 1993, Hughes and Diaz 1994, Crowley and Lowery 2000, Bradley et al. 2003). The settlement period of the Blue Lake sedimentary record is divided into 2 zones based on the ecological impacts of the early pioneers and the gradual change in landuse policy through the 20th century: settlement 


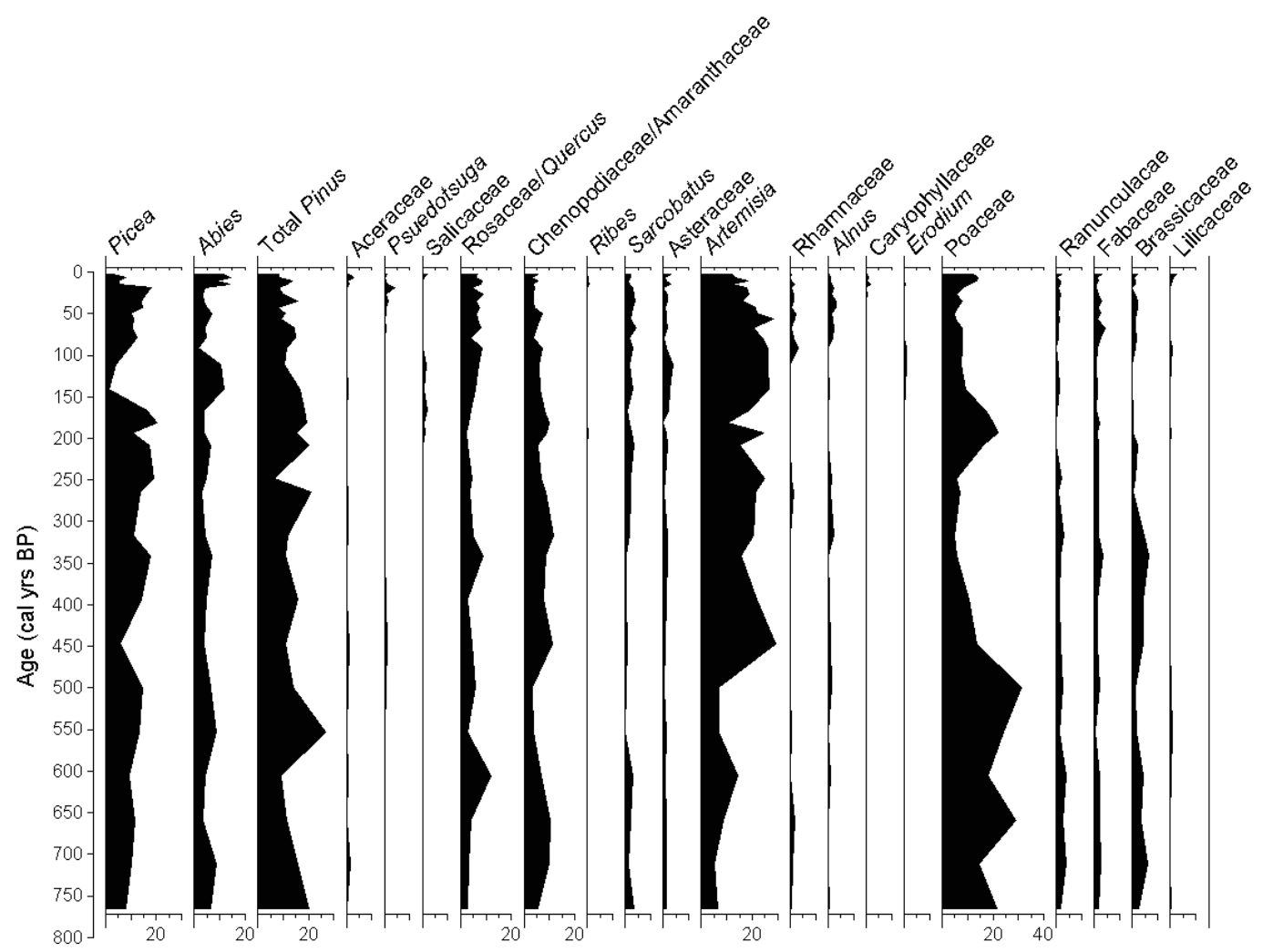

Fig. 2. Pollen diagram for the last 750 calendar years before present for Blue Lake, Utah.

by pioneers (150-100 cal yr BP, or ca. 1850-1900 $\mathrm{AD})$ and modern period (100 cal yr BP to present, or 1900-2005 AD).

\section{Presettlement}

Termination of Medieval Climate anOMALY (750-700 CAL YR BP).--Poaceae (max. 21\%) and Pinus UD (max. 20\%) are dominant at the conclusion of the MCA (Fig. 3). Picea (min. 8\%) and Artemisia (min. 6\%) are at their lowest percentages during the presettlement period. The mustard family, Brassicaceae (max. 6\%), is well established for this portion of the record. Charcoal accumulation (influx) is low at the conclusion of the MCA, at 2 particles per $\mathrm{cm}^{2}$ per year (Fig. 2). Magnetic susceptibility exhibits little variability (within 1 standard unit). Carbonates rise sharply at this point in the record, from $20 \%$ (min.) to $26 \%$ (max.).

TRANSITION PERIOD BETWEEN MCA AND LIA (700-500 CAL YR BP).-Poaceae (max. 29\%), Pinus UD (max. 26\%), and Rosaceae/Quercus (max. 12\%) are at their maximum for the entire record during this period; while Picea (max. 13\%) and Artemisia (max. 14\%) percentages are reduced from the earlier period (Fig. 2). Brassicaceae decline in the record from previous values to a minimum of $2 \%$. Charcoal accumulation is low, with no more than 4 particles per $\mathrm{cm}^{2}$ per year accumulating at any time during this period. At $600 \mathrm{cal}$ yr BP, charcoal accumulation becomes very low $\left(<2 \mathrm{~cm}^{3}\right)$. Magnetic susceptibility exhibits minimal variability $(<1$ standard unit). Carbonates decline steadily during this period, dropping from $24 \%$ to $18 \%$.

Little ICE Age (500-150 CAL YR BP).Picea (max. 20\%), Rosaceae/Quercus (max. 8\%), and Artemisia (max. 29\%) thrive in cold LIA climate conditions; whereas Poaceae are at their lowest occurrence (min. 7\%) of the presettlement period (Fig. 2). Pinus UD (max. 21\%) is relatively stable throughout the LIA as is Rosaceae/Quercus (max. 8\%). Brassicaceae (max. $7 \%$ ) increase during this period. Three events at 447, 317, and 208 cal yr BP appear to 


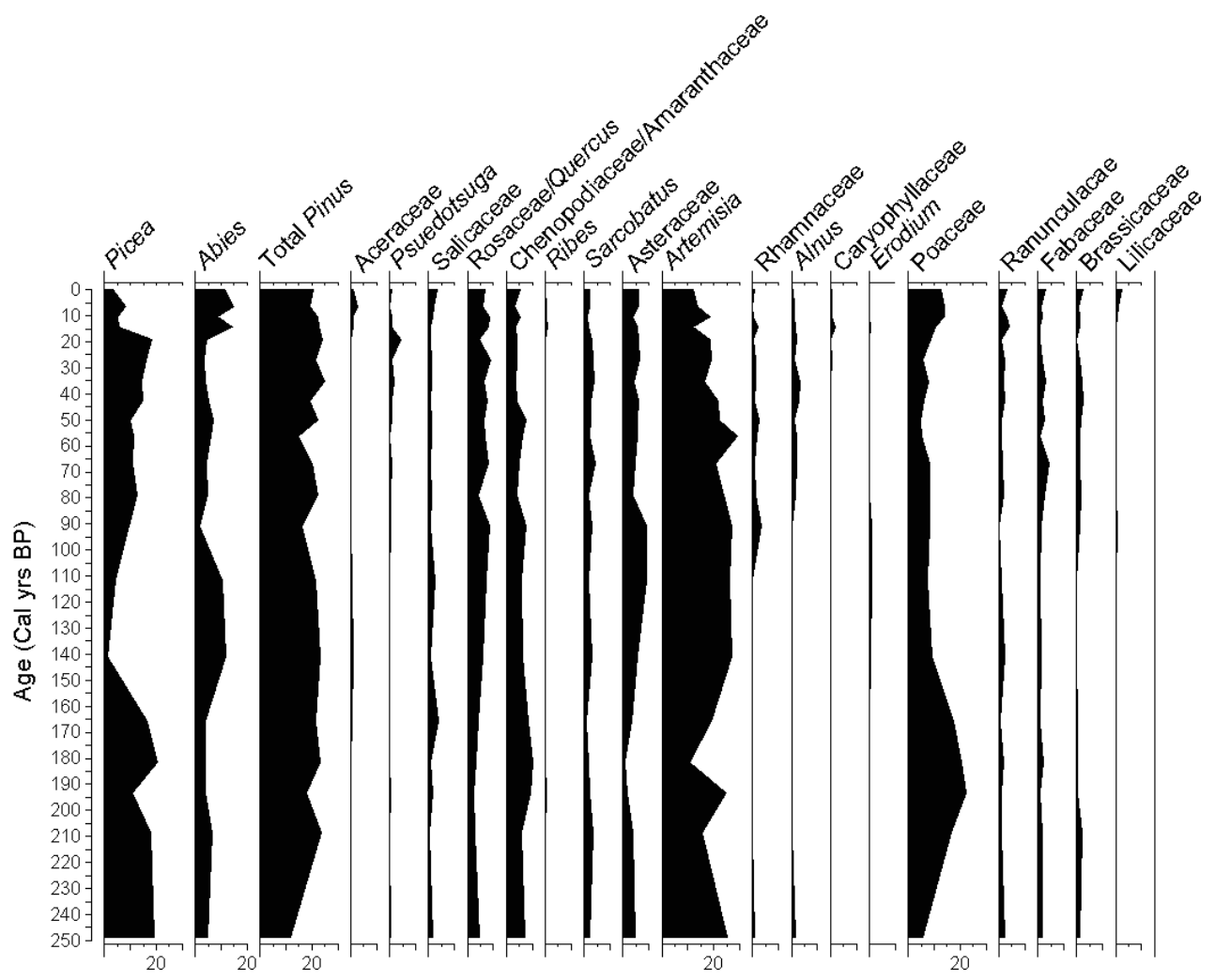

Fig. 3. Pollen diagram for the last 250 calendar years before present for Blue Lake, Utah.

have similar pollen signals characterized by brief decreases in Picea and Abies taxa and subsequent returns to levels similar to those preceding the event. All 3 events are marked by brief decreases in pollen percentages for Picea (by 9\%, 6\%, and 7\%, respectively), Abies (3\% at all 3 events), and Rosaceae/Quercus $(2 \%, 4 \%$, and $<1 \%$, respectively); while percentages of other taxa increase, specifically Artemisia (22\%, 8\%, and 9\%, respectively) and Chenopodiaceae/Amaranthaceae $(8 \%, 4 \%$, and $3 \%$, respectively). Charcoal accumulation during the LIA fluctuates between 9 and 0 fragments per $\mathrm{cm}^{2}$ per year, with 3 distinct peaks greater than 7 charcoal fragments per $\mathrm{cm}^{3}$ at 447,317 , and $275 \mathrm{cal}$ yr BP. Magnetic susceptibility values are not consistent, ranging from 2 standard units in the early LIA to near zero around 400 $\mathrm{BP}$ and returning to 2 standard units at $250 \mathrm{cal}$ yr BP. Carbonates exhibit limited variability during this period. Percentage values range between $16 \%$ and $28 \%$, with one significant drop in carbonate percentage around $365 \mathrm{cal} \mathrm{yr}$
BP, in which values fell from $24 \%$ to $16 \%$, then returned quickly to $26 \%$.

\section{Settlement}

SetTLEMENT BY Pioneers (1850-1900 AD / 150-100 CAL YR BP).- - As the LIA terminates at 150 cal yr BP (1850 AD), Poaceae rise to levels similar to those at the conclusion of the MCA (max. 20\%; Fig. 3). Shortly after settlement, Poaceae pollen is significantly reduced (min. 7\%). As Poaceae decline from 53\% to $28 \%$, shrub species increase rapidly, most notably Artemisia (min. 10\% to max. 26\%) and Rosaceae/Quercus (min. 3\% to max. 7\%). Picea pollen decreases significantly to the lowest point in the record (max. $20 \%$ to min. $1 \%$ ), while Abies (min. 2\% to max. 11\%) and Pinus (min. 3\% to max. $11 \%$ ) pollen rise. Brassicaceae are absent from the record during this period. Charcoal concentrations are low, at $\leq 2$ particles per $\mathrm{cm}^{3}$. Magnetic susceptibility rises by 4 standard units while carbonate percentages decline from $26 \%$ to $22 \%$ following pioneer settlement. 

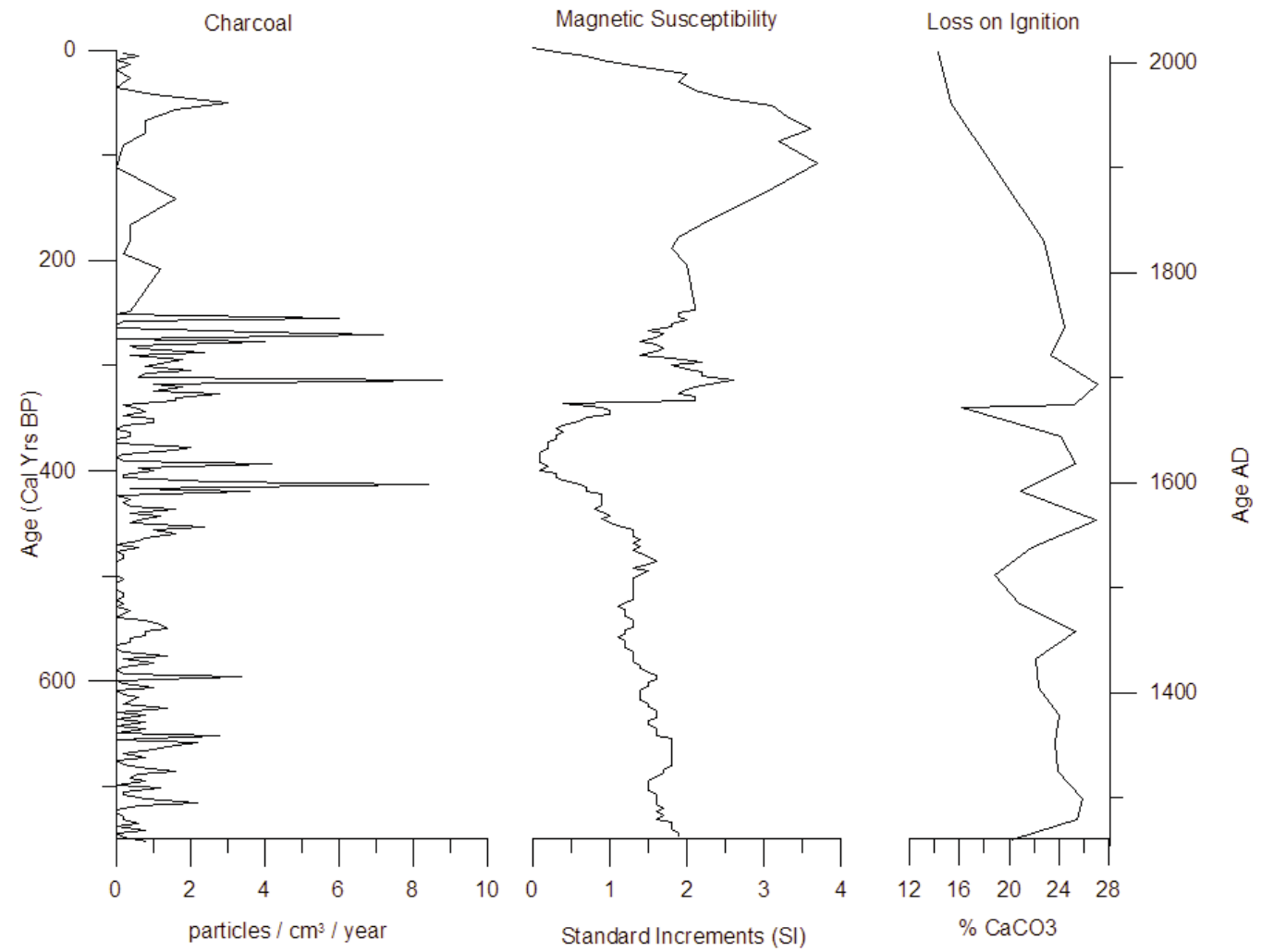

Fig. 4. Blue Lake charcoal, magnetic susceptibility, and loss-on-ignition data for the last 750 calendar years before present.

Modern Period (1900-2005 AD / 100-0 CAL YR BP).-Through the 1900s, Poaceae rise steadily (max. 14\%), Artemisia gradually declines (min. 7\%), Rosaceae/Quercus stabilize (max. $5 \%$ ), and Chenopodiaceae/Amaranthaceae (max. 3\%) decrease quickly and then stabilize (Figs. 3, 4). Picea gradually returns to dominance (max. 20\%) before decreasing sharply in the 1980s AD (min. 3\%). Abies decreases slightly (min. 5\%) and then increases quickly (max. 14\%) during the 1980s AD. Pinus UD gradually increases throughout the 1900s (max. 13\%). Brassicaceae (min. $1 \%$ ) return to the record early in the $1900 \mathrm{~s}$ and rise slowly (max. 2\%). Charcoal accumulation during this period does not exceed 4 particles per $\mathrm{cm}^{2}$ per year. Magnetic susceptibility continues to rise to 5 standard units before returning to 0 in the most recent portion of the record. Carbonates also are reduced toward the earliest portion of the record $(12 \%)$.

\section{DISCUSSION}

Presettlement (1255-1850 AD / 750-155 cal yr BP)

Before the arrival of the pioneers (generally known as the MCA and LIA periods), the vegetative structure on the Wasatch Plateau appeared to be responding to climate variability observed elsewhere in western North America (Bradley and Jones 1993, Hughes and Diaz 1994, Crowley and Lowery 2000, Bradley et al. 2003). The MCA portion of the Blue Lake record is limited to the last 50 years of the MCA; therefore, any broad evaluation of the vegetative responses or conditions during this period would be based on insufficient data. However, the dominance of Poaceae and Pinus at the termination of the MCA is consistent with persistently warm conditions across western North America (Crowley and Lowery 2000, Bradley et al. 2003). 
TABLE 2. Summary of inferred disturbance from Blue Lake sediments.

\begin{tabular}{|c|c|c|c|c|c|}
\hline $\begin{array}{l}\text { Timing of event } \\
\text { (cal yr BP / year AD) }\end{array}$ & $\begin{array}{c}\text { Decreasing } \\
\text { species (pollen) }\end{array}$ & $\begin{array}{c}\text { Increasing } \\
\text { species (pollen) }\end{array}$ & Charcoal peak & $\begin{array}{l}\text { Magnetic } \\
\text { susceptibility } \\
\text { response }\end{array}$ & Disturbance \\
\hline 16 / 1989 AD & Picea, Artemisia & $\begin{array}{c}\text { Abies, Pinus, Poaceae, } \\
\text { Rosaceae/Quercus }\end{array}$ & No & Decrease & Spruce beetle \\
\hline $150 / 1855 \mathrm{AD}$ & $\begin{array}{l}\text { Picea, Poaceae, } \\
\text { Cheno/Am }\end{array}$ & $\begin{array}{c}\text { Abies, Pinus, } \\
\text { Artemisia, } \\
\text { Rosaceae/Quercus }\end{array}$ & No & Increase & Human (logging) \\
\hline $208 / 1797 \mathrm{AD}$ & $\begin{array}{c}\text { Picea, Abies, } \\
\text { Pinus, Poaceae, } \\
\text { Artemisia }\end{array}$ & Cheno/Am & Yes & Decrease & Fire episode \\
\hline $317 / 1688$ AD & $\begin{array}{c}\text { Picea, Abies, } \\
\text { Rosaceae/Quercus }\end{array}$ & $\begin{array}{l}\text { Pinus, Artemisia, } \\
\text { Cheno/Am }\end{array}$ & Yes & Peak & Fire episode \\
\hline 447 / $1558 \mathrm{AD}$ & Picea, Poaceae & $\begin{array}{l}\text { Artemisia, } \\
\text { Cheno/Am, } \\
\text { Brassicaceae }\end{array}$ & Yes & Peak & Fire episode \\
\hline
\end{tabular}

Historical accounts are nonexistent for the MCA presettlement portions of the Blue Lake record from the Wasatch Plateau. However, historical records published in Hall (2001) from the conclusion of the LIA suggest that subalpine meadows were dominated by tall, dense grasses and forbs, and subalpine forests were composed of Picea and Abies (Stewart 1941, Hall 2001). The Blue Lake pollen record supports this interpretation. Pollen from herbaceous taxa (e.g., Poaceae and Brassicaceae), as well as pollen from the arboreal species Picea and Abies, are generally more abundant and stable in the centuries preceding settlement.

Vegetative responses to climate have been recorded by Munroe (2003a) using repeat photography in the Uinta Mountains. Munroe (2003a) observed a lowering and thinning of treeline during the LIA, as well as a reduction in size of grassy, open meadows. Other records from the region are presented at a temporal scale too coarse to compare them with the centennially resolved vegetation changes from the Blue Lake record (Shafer 1989, Anderson et al. 1999, Munroe 2003b). However, records from these sites generally support the regional dominance of the arboreal species (Picea spp. and Abies spp.) at elevations greater than $3000 \mathrm{~m}$ during the LIA.

Charcoal accumulation from the Blue Lake sediments indicates little fire activity throughout presettlement. The onset of the LIA is accompanied by 3 probable fire events (447, 317 , and 208 cal yr BP) according to the pollen and charcoal records, with a mean firereturn interval of 127 years (Table 2). The size of the charcoal peaks associated with these events and the relatively short return interval suggests that small, infrequent fires characterize the fire regime of the Wasatch Plateau for the last $\sim 700$ years. All 3 probable fire events from the Blue Lake record occur during the LIA period. Longer-than-previous firereturn intervals during this period could be associated with cool LIA climate conditions and reduced convectional thunderstorm activity.

$$
\begin{gathered}
\text { Settlement }(150-100 \text { cal yr BP / } \\
1850-1900 \text { AD) }
\end{gathered}
$$

LOGGING IMPACTS.-Pioneers arrived in a portion of the Great Basin now called Utah in the summer of 1847 (Hall 2001). The harsh winters and heavy snowfall at high-elevation sites limited pioneer settlements to low-elevation valleys where winter climates were milder (Hall 2001). The dominance of xeric vegetation at these valley locations afforded settlers few opportunities to harvest wood for buildings and other wood products (Hall 2001). The general absence of trees and the limited water resources in the valleys led to extensive exploitation of the forested plateaus and mountain ranges. Subalpine forests in north and central Utah were either clear-cut or high-graded (removing only the larger trees) to provide construction materials, and numerous upland drainages were modified to meet the water demands for valley settlements (Stewart 1941, Hall 2001).

The pollen record clearly reflects the historically documented logging activities on the Wasatch Plateau (e.g., Hall 2001). The acute decline in Picea pollen, from $22 \%$ to $<1 \%$, at approximately 1850 AD suggests extensive logging of Picea. A concurrent increase in magnetic 
susceptibility indicates erosion associated with tree harvesting and subsequent overgrazing by domestic livestock (Hall 2001). Following the removal of the canopy-dominant Picea, Abies and Pinus pollen increase from 5\% and 6\% to $11 \%$ and $16 \%$, respectively. The fact that Abies and Pinus pollen do not decline suggests that these species were not of interest to loggers. Pinus flexilis in subalpine areas of the Wasatch Plateau is relatively small in height and diameter, which would limit its desirability as construction material. Abies lasiocarpa is likewise undesirable because it is susceptible to white heart rot (Haematostereum sanguinolenta and Phellinus pini) in large-diameter specimens (Blanchette 1982, Lewis and Lindgren 1999).

In the 750-year Blue Lake record, pollen deposition indicates that logging activities were more effective at removing the spruce signal from the landscape than natural disturbance events prior to logging. Several important differences are worth noting when comparing the Picea pollen abundance during logging in the 1850s with pollen abundance during other disturbance events (e.g., LIA fires or the 1980s spruce beetle epidemic). Logging operations removed nearly all (i.e., clearcut) spruce trees from subalpine areas of the Wasatch Plateau. Conversely, a spruce beetle epidemic allows some (generally, <5-inch $\mathrm{dbh}$ ) trees to remain on the landscape. Immature trees of this diameter offer limited cambium and phloem tissue to support completion of the spruce beetle life cycle (Schmid and Frye 1977). Therefore, surviving Picea will likely continue contributing to residual Picea pollen after the epidemic. Smaller diameter classes of $P$. engelmannii were noted to have a lower degree of tree mortality on the Wasatch Plateau during the 1980s epidemic (Dymerski et al. 2001). Additionally, blue spruce (Picea pungens) prevalent in many drainage basins on the Wasatch Plateau, is not as susceptible to spruce beetle attack and may have contributed to residual Picea pollen during the 1980s spruce beetle epidemic. Picea pungens would have been removed from the landscape during the 1850s logging event. The presence of $P$. pungens in the vicinity of Blue Lake and the less susceptible, smaller-diameter Engelmann spruce following the 1980s epidemic likely contributed to the differences in the Picea pollen signal between logging and spruce beetle events.
GRAZING IMPACTS.-European livestock was introduced to Utah with the arrival of the pioneers in the mid-1800s (Powell 2006). Grazing by sheep and cattle adversely affected the ecology of the Wasatch Plateau (Hall 2001). Near the beginning of the 20th century, foresters regarded the Wasatch Plateau as among the most adversely impacted landscapes in the western United States as a result of domestic ungulate overgrazing (Hall 2001). Across the West, historical accounts indicate that early overgrazing practices affected landscapes more significantly, in terms of length and severity, than other recorded historical disturbance events (Ellison 1954, Hall 2001).

Generally, the Blue Lake pollen record captures the arrival of livestock and subsequent heavy grazing with a significant decline in preferred forage vegetation (e.g., Poaceae) and a concurrent rise in nonforage shrubs, such as Artemisia (see 1850 AD, Fig. 3). However, the pollen record does not indicate the grazing disturbance as conspicuously as it does the logging disturbance. The understated pollen response may be due, in part, to the fact that many herbaceous forage species are adapted for animal pollination (zoophilous) whereas many conifer species are wind pollinated (animophilous). Thus herbaceous pollen is less likely to enter the lake than arboreal pollen (Faegri et al. 1989). Grazing-induced vegetation changes, particularly with decreases in Poaceae, have been observed in other sedimentary and ecological studies in the American West (Dull 1999, Hall 2001).

In 1910, much of the Wasatch Plateau became protected as a Forest Reserve in an effort to preserve what was left of the fragmented and denuded landscape. Forest Reserve status limited the number of cattle and sheep that could forage on the Wasatch Plateau and also regulated timber-harvesting activities. Though the initial logging and livestock limits under the Forest Reserve were not as stringent as later measures that further reduced harvesting and grazing, a modest amount of recovery is evident in the pollen record. Poaceae and other herbaceous taxa (e.g., Brassicaceae) return to values similar to those observed before the arrival of pioneers (Fig. 3). Nonforage species (e.g., Artemisia and Ambrosia) level off and subsequently decline throughout the 1900 s (Fig. 3). The recovery of the dominant arboreal species, Picea, due to logging restrictions is also evident in the pollen record (Fig. 3). 
SPRUCE BEETLE IMPACTS.-The 1980s spruce beetle epidemic on the Wasatch Plateau is recorded clearly in the Blue Lake pollen record. Picea pollen declines sharply after the onset of the 1987 epidemic affecting the Blue Lake area. In mature spruce-fir forests, longer-lived and taller Picea trees suppress the growth of Abies by limiting sunlight (Whipple and Dix 1979). In response to Picea engelmannii mortality, Abies pollen increases sharply in 1989, suggesting that Abies thrived in the newly created openings caused by the loss of the spruce overstory. This release in Abies growth following beetle-induced Picea engelmannii mortality has also been observed and documented through tree-ring analysis in numerous epidemics in western Colorado (Veblen et al. 1991, 1994, Eisenhart and Veblen 2000, Kulakowski et al. 2003) and in a USDA Forest Service study in western Colorado (Schmid and Hinds 1974).

Historic observations of spruce beetle epidemics document beetle carcasses accumulating in large enough quantities that beetle remains would likely be preserved in the sedimentary record (Schmid and Frye 1977). During an epidemic on the White River Plateau, Colorado, spruce beetle carcasses were observed on the eastern lakeshore in a layer measuring 6 inches deep, 6 feet wide, and more than a mile long (Schmid and Frye 1977). The presence of beetle macrofossils would be a crucial piece of evidence in understanding the periodicity, role, and ecological implications of landscape-scale spruce beetle epidemics in the western high-elevation spruce-fir ecosystem. These macrofossil records would provide a much longer data set of historic disturbance events than tree-ring analysis techniques. Indeed, recent examination of lake sediments from the northern Rockies corroborates this possibility with macrofossil remains of Dendroctonus ponderosae (mountain pine beetle) identified in a lake sediment core (Brunelle et al. 2008). While these results are encouraging, the absence of identifiable beetle macrofossils (and other terrestrial insect macrofossils) from the Blue Lake sediments confirms that more research is needed to understand the mechanisms affecting preservation of beetle remains in the sedimentary record.

In sedimentary layers from Blue Lake, we observed chitinous residues that corresponded temporally to the 1980 s epidemic of spruce beetles. However, these insect remains were chemically deteriorated beyond identification. Chitin can be used to create a gelatin-like material for medicinal capsules, and a review of pharmaceutical literature on chitin solubility in water indicates that chitin is susceptible to decay in both alkaline- and acidic-pH environments. Laboratory observations cited in Sugimoto et al. (1998) and Nemstev et al. (2004) show that chitin is susceptible to dissolution in $\mathrm{pH}$ environments $<4$ and $>8$. Additionally, these and other findings document a persistent rubbery trace protein called resilin, which often remains following partial dissolution of chitin (Weis-Fogh 1960, Sugimoto et al. 1998, Nemstev et al. 2004). The instability of chitin in acidic and basic systems could explain the insect smear observed in the Blue Lake record. The $\mathrm{pH}$ of Blue Lake measured during sediment retrieval was 8.5 , which demonstrates that the water chemistry at Blue Lake is not ideal for beetle preservation. Further research is needed to establish any potential relationship between lake water chemistry and beetle-specific chitin solubility/preservation.

The absence of identifiable insect macrofossils forced the reliance on pollen and other proxy measures listed below to identify potential diagnostic signals of spruce beetle epidemics. Table 2 lists the timing of noteworthy decreases in Picea pollen (i.e., decreases relative to surrounding abundance), charcoal concentration, magnetic susceptibility, and pollen taxa responding at the same time as the Picea decline. Based on the observed decline of Abies pollen during the pre-1850 observed declines in Picea, it appears unlikely that another spruce beetle epidemic similar to the 1980s epidemic occurred in the 750-year Blue Lake record. The absence of an Abies pollen release similar to the one observed following postsettlement logging and during the 1980s spruce beetle event suggests that during other disturbance events over the last 750 years, the understory species were impacted along with the canopydominant Picea. Localized spruce beetle outbreaks may have occurred during the time frame of this record, though their overall impact was not reflected in the pollen record as clearly as the 1980s outbreak.

FIRE IMPACTS.-During the settlement period, no historical documentation of wildfire exists for the Blue Lake watershed. Pollen and charcoal signals are not consistent with fire 
signals displayed during the LIA. The lack of wildfire evidence during the settlement period suggests that high-intensity wildfire has not played a significant role in shaping the vegetative ecology of the Wasatch Plateau since 1850 AD. Potential explanations for reduced fire since 1850 AD include removal of Picea following the 1850 logging event, which limited available fuel for wildfire. Also, fine-fuel reductions resulting from prolonged grazing activities and wildfire suppression policies that began throughout the west in the early 1900s may have also contributed to the absence of highseverity wildfire events.

\section{Conclusions}

The MCA portion of the record suggests that, consistent with warmer conditions in western North America, vegetative conditions were dominated by Poaceae and Pinus. The LIA portion of the Blue Lake record represents a landscape dominated by forbs, tall grasses, and the arboreal species Picea and Abies in response to cooler conditions. Occurrence of fire during LIA appears elevated and may be due to limited summer precipitation from subdued convective thunderstorm activity during this relatively cooler period. Charcoal accumulations are modest, suggesting that the fires were perhaps localized.

Settlers arrived along Utah's Wasatch Plateau in the mid-1800s, with 1847 as the most commonly cited arrival date (Stewart 1941, Hall 2001, Powell 2006). Historically documented human activities on the Wasatch Plateau (e.g., logging and livestock grazing) are recorded in the sedimentary record. The decline in Picea pollen and the decrease in Poaceae pollen provide compelling evidence for historical accounts of significant ecological effects following human settlement in Utah. The severity of Picea pollen decline associated with logging is unprecedented elsewhere in the 750-year record. The decline in Poaceae, likely a result of livestock grazing, is evident in the pollen record, though similarly low levels of Poaceae pollen were recorded during the LIA. Abies and Pinus pollen show increases following the historically documented logging and spruce beetle disturbances, due primarily to the decline in canopy-dominant Picea. Pinus flexilis and Abies lasiocarpa are not hosts for spruce beetle, nor are they economically viable alternatives for construction materials. These characteristics explain their prominence on the landscape following logging activities and the spruce beetle epidemic.

The Blue Lake record indicates that fire played a role in modifying the Wasatch Plateau during the LIA. However, fire does not have any detectable role in shaping the modern ecology on the Wasatch Plateau. The spruce beetle epidemic during the 1980s has contributed more to current vegetative structure than any other natural disturbance event in the 750-year Blue Lake record. A longer temporal record is required to determine whether spruce beetle events have occurred before the 750 -year Blue Lake record. As a result of this study, it does not appear that any other severe spruce beetle epidemics have occurred over the past 750 years at Blue Lake prior to the most recent epidemic initiated in the mid1980s. This observation is a single data point and so not yet comparable to research in Colorado (Veblen et al. 1991, Veblen et al. 1994, Eisenhart and Veblen 2000).

\section{ACKNOWLEDGMENTS}

The authors thank the University of Utah Funding Incentive Seed Grant Program and the Joint Fire Science Program (Project No. 06-3-1-31) for funding this research. Thanks also to Larry Coats for insightful and constructive reviews; Liz Hebertson for assisting with lake selection; J.J. Shinker, Stacy Randolph Morris, Shela Patrickson, Jessica Spencer, Todd Daines, Lesleigh Anderson, and Thomas A. Minkley for assistance with fieldwork; and Tom Shore, Mesia Nyman, and Diane Cote on the Manti-La Sal National Forest for their cooperation and support. Thank you to the Western North American Naturalist reviewers for providing suggestions to improve this manuscript. This is RED Lab contribution \#7.

\section{Literature Cited}

Anderson, R.S., J. Hasbargen, P.A. Koehler, and E.J. FEILER. 1999. Late Wisconsin and Holocene subalpine forests of the Markagunt Plateau of Utah, Southwestern Colorado Plateau, U.S.A. Arctic, Antarctic and Alpine Research 31:366-378.

BAKER, W.L., AND T. VEBLEN. 1990. Spruce beetles and fire in the nineteenth-century subalpine forests of western Colorado, U.S.A. Arctic and Alpine Research 22:65-80.

Bassett, I.J., C.W. Crompton, and J.A. Parmlee. 1978. An atlas of airborne pollen grains and common fungal spores. Biosystematics Research Institute, Ottawa, Ontario, Canada. 
Bebi, P., D. Kulakowski, and T. Veblen. 2003. Interactions between fire and spruce beetles in a Rocky Mountain forest landscape. Ecology 84:362-371.

Birks, H.H. 2001. Plant macrofossils. Pages 49-74 in J.P. Smol, H.J.B. Birks, and W.M. Last, editors, Tracking environmental change using lake sediments. Volume 3. Kluwer Academic Publishers, Dordrecht, The Netherlands.

Blanchette, R.A. 1982. Decay and canker formation by Phellinus pini in white and balsam fir (Abies concolor and Abies balsamea). Canadian Journal of Forest Research 12:538-544.

Bradley, R.S., M.K. Hughes, and H.F. Diaz. 2003. Climate in Medieval time. Science 302:404-405.

Bradley, R.S., and P.D. Jones. 1993. "Little Ice Age” summer temperature variations: their nature and relevance to recent global warming trends. Holocene 3:367-376.

Brunelle, A., J. Rehfeldt, B. Bentz, and S. Munson. 2008. Holocene records of mountain pine beetle infestation in the U.S. Northern Rocky Mountains. Forest Ecology and Management 255:836-846.

Clark, J.S. 1988. Particle motion and the theory of stratigraphic charcoal analysis: source area, transportation, deposition and sampling. Quaternary Research 30: 81-91.

Crowley, T.J., AND T.S. Lowery. 2000. Northern hemisphere temperature reconstruction. Ambio 29:51-54.

DEAN, W.E., JR. 1974. Determination of carbonate and organic matter in calcareous sediments by loss on ignition: comparison to other methods. Journal of Sedimentary Petrology 44:242-248.

DeRose, R.J., AND J.N. LONG. 2007. Disturbance, structure, and composition: spruce beetle and Engelmann spruce on the Markagunt Plateau, Utah. Forest Ecology and Management 244:16-23.

Donato, D.C., J.B. Fontaine, J.L. Campbell, W.D. Robinson, J.B. Kauffman, and B.E. LaW. 2006. Postwildfire logging hinders regeneration and increases fire risk. Science 311:352.

DulL, R. 1999. Palynological evidence for 19th century grazing-induced vegetation changes in the southern Sierra Nevada, California, U.S.A. Journal of Biogeography 26:899-912.

Dymerski, A.D., J.A. Anhold, And A.S. Munson. 2001. Spruce beetle (Dendroctonus rufipennis) epidemic in Engelmann spruce (Picea engelmannii) in central Utah, 1986-1998. Western North American Naturalist 61:19-24.

EisenharT, K.S., AND T.T. VEBLEN. 2000. Dendroecological detection of spruce bark beetle epidemics in northwestern Colorado. Canadian Journal Forest Research 30:1788-1798.

Ellison, L. 1954. Subalpine vegetation on the Wasatch Plateau, Utah. Ecological Monographs 24:89-184.

Erdtman, G. 1952. Pollen morphology and plant taxonomy: angiosperms. Almqvist and Wiksell, Stockholm, Sweden.

FaegRi, K., P.E. KaLAnd, AND K. KzYWInski. 1989. Textbook of pollen analysis. John Wiley \& Sons, New York, NY.

Gedye, S.J., R.T. Jones, W. Tinner, B. Ammann, and F. OLDFIELD. 2000. The use of mineral magnetism in the reconstruction of fire history: a case study from Lago di Origlio, Swiss Alps. Palaeogeography, Palaeoclimatology, Palaeoecology 164:101-110.

GiLlson, L., AND M.T. Hoffman. 2007. Rangeland ecology in a changing world. Science 315:53-54.
HALL, M. 2001. Repairing mountains: restoration, ecology and wilderness in twentieth-century Utah. Environmental History 6:574-600.

Hansen, E.M., B.J. Bentz, and D.L. Turner. $2001 \mathrm{a}$. Physiological basis for flexible voltinism in the spruce beetle (Dendroctonus: Scolytidae). Canadian Entomologist 133:805-817.

2001b. Temperature-based model for predicting univoltine brood proportions in spruce beetle (Dendroctonus: Scolytidae). Canadian Entomologist 133: 827-841.

Hebertson, E.G. 2003. A biological evaluation of spruce beetle activity on Barney Top. USDA Forest Service Publication OFO-BE-03-001, S\&PF Forest Health Protection, Ogden Field Office, UT. 19 pp.

Hebertson, E.G., AND M.J. Jenkins. 2008. Climate factors associated with historic spruce beetle (Coleoptera: Curculionidae) epidemics in Utah and Colorado. Environmental Entomology 37:282-292.

Holsten, E.H., P.J. Shea, And R.R. Borys. 1999. MCH released in non-pheromone dispenser prevents spruce beetle, Dendroctonus rufipennis (Coleoptera: Scolytidae), attacks in south-central Alaska. Journal of Economic Entomology 96:31-34.

Hughes, M.K., AND H.F. Diaz. 1994. Was there a 'Medieval Warm Period,' and if so, where and when? Climate Change 26:109-142.

Jenkins, M.J., C.A. Dicus, and E.G. Hebertson. 1998. Postfire succession and disturbance interactions on an intermountain subalpine spruce-fir forest. Pages 219-229 in T.L. Pruden and L.A. Brennan, editors, Fire in ecosystem management: shifting the paradigm from suppression to prescription. Tall Timbers Fire Ecology Conference Proceedings, No. 20. Tall Timbers Research Station, Tallahassee, FL.

Kapp, R.O., O.K. Davis, AND J.E. KING. 2000. Pollen and spores. 2nd edition. American Association of Stratigraphic Palynologists, New York, NY.

Kipfmueller, K.F., AND W.L. BaKer. 2000. A fire history of a subalpine forest in southeastern Wyoming, USA. Journal of Biogeography 27:71-85.

Kolb, T., M. Wagner, and W. Covington. 1994. Concepts of forest health. Journal of Forestry 92:10-15.

KulakowsKi, D., AND T. VEblen. 2003. Subalpine forest development following blowdown in the Mount Zirkel Wilderness, Colorado. Journal of Vegetation Science 14:653-660.

Kulakowski, D., T. Veblen, and P. Bebi. 2003. Effects of fire and spruce beetle outbreak legacies on the disturbance regime of a subalpine forest in Colorado. Journal of Biogeography 30:1445-1456.

LEWIS, K.J., AND B.S. LiNDGREN. 1999. Influence of decay fungi on species composition and class structure in mature Picea glauca $\times$ engelmannii and Abies lasiocarpa in sub-boreal forests of central British Columbia. Forest Ecology and Management 123:135-143.

Logan, J.A., AND J.A. POWELL. 2001. Ghost forest, global warming and the mountain pine beetle (Coleoptera: Scolytidae). American Entomologist 47:160-172.

Marchetti, D.W., T.E. Cerling, And E.W. LiPs. 2005: A glacial chronology for the Fish Creek drainage of Boulder Mountain, Utah, USA. Quaternary Research 64:264-271.

Mattson, W.J. 1996. Escalating anthropogenic stresses on forest ecosystems: forcing benign plant-insect interactions into new interaction trajectories. Pages 338-342 in E. Korpilahti, H. Mikkelä, and T. Salonen, editors, 
Caring for the forest: research in a changing world Congress report, Volume 2. IUFRO World Congress Organizing Committee, Finland.

MitcheLL, V. 1976. The regionalization of climate in the western United States. Journal of Applied Meteorology 15:920-927.

Mock, C.J. 1996. Climate controls and spatial variations of precipitation in the western United States. Journal of Climate 9:1111-1125.

Munroe, J.S. 2003a. Estimates of Little Ice Age climate inferred through historical rephotography, northern Uinta Mountains, U.S.A. Arctic, Antarctic, and Alpine Research 35:489-498.

2003b. Holocene timberline and paleoclimate of the northern Uinta Mountains, northeastern Utah, USA. Holocene 13:175-185.

Nemstev, S.V., O.Y. Zueva, M.R. Khismatullin, A.I. ALBULOV, AND V.P. VARLAMOV. 2004. Isolation of chitin and chitosan from honeybees. Applied Chemistry and Microbiology 40:39-43.

Osborn, G., And K. Bevis. 2001. Glaciation in the Great Basin of the western United States. Quaternary Science Reviews 20:1377-1410.

PeEt, R.K. 2000. Forests and meadows of the Rocky Mountains. Pages 75-121 in M.G. Barbour and W.D. Billings, editors, North American terrestrial vegetation. Cambridge University Press, Cambridge, United Kingdom.

Petersen, K.L. 1994. Modern and Pleistocene climatic patterns in the West. Pages 27-54 in K.T. Harper L.L. St. Clair, K.H. Thorne, and W.M. Hess, editors, Natural history of the Colorado Plateau and Great Basin. University Press of Colorado, Boulder, CO. $308 \mathrm{pp}$.

Powell, A.K., EDITOR. 2006. Utah history encyclopedia: pioneer arrival, settlement and activities in Utah. University of Utah, Salt Lake City, UT; [cited 14 December 2006]. Available from: http://www.media .utah.edu/.

Raffa, K.F., B.H. Aukema, B.J. Bentz, A.L. Carroll, J.A. Hicke, M.G. Turner, and W.H. Romme. 2008 Cross scale drivers of natural disturbance prone to anthropogenic amplification: the dynamics of bark beetle eruptions. BioScience 58:501-517.

Rebertus, A.J., T.T. Veblen, L.M. Roovers, And J.N. MAST. 1992. Structure and dynamics of old-growth Engelmann spruce-subalpine fir forests in Colorado. Pages 139-153 in Old-growth forests in the southwest and Rocky Mountain regions: proceedings of a workshop: March 9-13, 1992, Portal, Arizona. General Technical Report RM-GTR-213, USDA Forest Service, Fort Collins, CO.

Romme, W.H., AND D.H. KNight. 1981. Fire frequency and subalpine forest succession along a topographic gradient in Wyoming. Ecology 62:319-326.

Schmid, J.M., AND J. Frye. 1977. Spruce beetle in the Rockies. General Technical Report RM-49, Rocky
Mountain and Range Experiment Station, USDA Forest Service.

SChMid, J.M., AND T.E. Hinds. 1974. Development of spruce-fir stands following spruce beetle outbreaks. Research Paper RM-131, Rocky Mountain Forest and Range Experiment Station, USDA Forest Service.

ShaFER, J.L. 1989. The timing of late Quaternary monsoon precipitation maxima in the southwest United States. Doctoral dissertation, University of Arizona, Tucson, AZ.

SPIEKER, E.M., AND M.P. Billings. 1940. Glaciation in the Wasatch Plateau. Geological Society of America Bulletin 51:1173-1198.

STEWART, G. 1941. Historic records bearing on agriculture and grazing ecology in Utah. Journal of Forestry 39: 362-375.

Stuiver, M., P.J. Reimer, And T.F. Braziunas. 1998. High precision radiocarbon age calibration for terrestrial and marine samples. Radiocarbon 40:1127-1151.

Sugimoto, M., M. Morimoto, H. Sashiwa, H. Saimoto, AND Y. SHIGEMasa. 1998. Preparations and characterization of water-soluble chitin and chitosan derivatives. Carbohydrate Polymers 36:49-59.

Veblen, T.T., K.S. Hadley, E.M. Nel, T. Kitzberger, M. REID, AND R. VILlaba. 1994. Disturbance regime and disturbance interactions in a Rocky Mountain subalpine forest. Journal of Ecology 82:125-135.

Veblen, T.T., K.S. Hadley, M.S. Reid, and A.J. Rebertus. 1991. Methods of detecting past spruce beetle outbreaks in Rocky Mountain subalpine forests. Canadian Journal of Forest Research 21:242-254.

Wannamaker, P.E., J.M. Bartley, A.F. Sheehan, C.H. Jones, A.R. LOWry, T.A. Dumitru, T.A. Ehlers, W.S. Holbrook, G.L. Farmer, M.J. Unsworth, et al. 2001. Great Basin-Colorado Plateau transition in central Utah: an interface between active extension and a stable interior. Pages 1-26 in M.C. Erskine, J.E. Faulds, J.M. Bartley, P. Rowley, editors, The geological transition: Colorado Plateau to Basin and Range. Proceedings of the J. Hoover Mackin Symposium, Utah Geologic Association and American Association of Petroleum Geologists Publication 30/GB78, Cedar City, Utah, September 20-23, 2001.

WeIs-FogH, T. 1960. A rubber-like protein in insect cuticle. Journal of Experimental Biology 37:889-907.

Whipple, S.A., And R.L. Dix. 1979. Age structure and successional dynamics of a Colorado subalpine forest. American Midland Naturalist 101:142-158.

Whitlock, C., AND S.H. Millspaugh. 1996. Testing the assumptions of fire-history studies: an examination of modern charcoal accumulation in Yellowstone National Park, USA. Holocene 6:7-15.

Received 16 September 2008 Accepted 4 December 2009 